\title{
EU ENERGY SECURITY AT A GLANCE: THE EVOLUTION OF THE SITUATION BETWEEN 2014-2018
}

\author{
Ionuț Alin CÎRDEI \\ "Nicolae Bălcescu" Land Forces Academy, Sibiu, Romania \\ cirdei_alin@yahoo.com
}

\begin{abstract}
Ensuring the energy resources needed for the functioning of society as a whole is a major concern for European countries, which must identify solutions in this regard. Measures to be taken individually and collectively aim to ensure a continuous flow of energy resources and to consolidate the energy security. The energy security of European states is quite difficult to achieve due to the energy situation of all states and due to the increased dependence on energy resources outside the European space. Ensuring energy security not only creates the conditions for the development of society, but also strengthens national security, as it eliminates possible sources of tension and contradictions, which can lead to crisis or even conflict. From this perspective, it is clear that the EU is making efforts for energy sources diversification and to reduce the likelihood of malfunctions, but the evolution of the energy situation of the EU bloc shows that this is a long-term approach and concrete measures are very difficult to implement, fact easy to notice from the analysis of the energy situation of the EU between 2014 and 2018.
\end{abstract}

KEYWORDS: energy security, renewable energy, national security, dependence

\section{Introduction}

The European Union is a large consumer of energy resources due to its extremely high economic and industrial potential and due to the high standard of living of the population, which is a large consumer of energy. In order to satisfy its appetite for energy resources, the European Union can only rely to a small extent on its own resources, which means that the degree of dependence on imported energy resources, especially in terms of hydrocarbons, is extremely high, as we can identify EU states which are almost entirely dependent on resources from outside the Union (i.e. Malta, Cyprus, Luxembourg). Aware that this dependence on energy resources outside the Union is one of the greatest vulnerabilities, with effects on all areas and all states, the EU has launched a series of actions aimed at reducing dependence and achieving energy diversification, simultaneously with identifying new opportunities to transform the economy to become more sustainable. Among the measures taken we can list the setting of targets for increasing the share of energy from renewable sources in the EU to $20 \%$ in 2020 and up to $32 \%$ in 2030 , as well as projects aimed at diversifying energy sources, building new transport routes and the interconnection of Member States' energy systems through projects of common interest in the field of energy.

\section{Scientific Tool}

For the scientific substantiation of this research we used the method of qualitative analysis of official documents 
and statistical data available to identify the current situation of the European Union in terms of energy availability, and to determine the evolution of the EU energy situation between 2014-2018, we used the method of quantitative analysis, which allowed us to identify short-and mediumterm trends in terms of the possibility of ensuring energy security.

\section{Analysis of the EU Energy Situation from the Development of the Energy Security Strategy until 2018}

The EU's energy situation has been in the spotlight of decision-makers for a long time, with the Union facing extensive challenges during the gas crises that brought Ukraine and Russia to the fore in 2006 and 2009, when EU states were collateral victims. The EU's vulnerability to hydrocarbons from Russia became a real threat to Member States' security in 2014, when Russia initiated and supported aggression against Ukraine. Following this aggression, which had the potential to provoke a new energy crisis for the Member States, the EU has developed an energy security strategy that aims to improve the Union's energy situation by taking multilevel measures. If we analyze the official figures for 2014, we can see that the concern of decision makers was fully justified, given that the European Union imported $53 \%$ of energy consumed, while oil imports were almost $90 \%$ and natural gas $66 \%$ of the total energy consumed (COM 330 final, 2014), and the main supplier, especially to the heavily industrialized states like Germany and Italy, was Russia. Taking into account the energy situation of the European Union in 2014, the EU's energy security strategy aims to encourage decisive action in several directions, such as "immediate actions aimed at increasing the EU's capacity to cope with a major disruption during the winter of 2014/2015, strengthening emergency/solidarity mechanisms that include the coordination of risk assessments and emergency plans; and protecting strategic infrastructure, moderating energy demand, building a fully functioning and well-integrated internal market, increasing energy production in the European Union, further developing energy technologies, diversifying external sources of supply and related infrastructure, improving the coordination of national energy policies and conveying a unitary message in foreign energy policy" (COM 330 final, 2014). By issuing this strategy, EU decisionmakers are in fact confirming the importance of ensuring energy security for Member States, through individual efforts, but especially through joint efforts, as the energy situation of one of the world's largest consumers of energy resources is very precarious, taking into account the perspective of increasing consumption and dependence on fossil energy resources from outside the union. The identified measures aim at overcoming immediate difficulties, related to possible supply disruptions, and also improving the energy security of member states in the medium and long term, by reducing consumption, increasing energy efficiency, identifying new energy suppliers, increasing the share of energy from sources renewable etc.

The use of energy from renewable sources can be considered as an alternative to traditional energy sources and at the same time can be a solution to reduce environmental impact and slow global warming, but increasing the share of renewable energy in the structure of the energy mix involves major investment and new technologies discovery in order to make this transition effective. In order to demonstrate its determination to promote renewable energy, an ambitious target has 
been set at EU level for 2020, namely to reach a share of $20 \%$ of total energy consumed for energy from renewable sources, a target that is tailored to the specifics of Member States. As this target is very likely to be reached, the EU has raised the stakes and set the share of renewable energy in the Union's final gross energy consumption in 2030 to be at least $32 \%$ (European Parliament, 2018). Once the statistical data are available for 2020, we will be able to confirm reaching the EU target of $20 \%$ in terms of the share of energy from renewable sources. What is certain is that, in 2014, according to statistical data provided by Eurostat, the share of renewable energy was $16.21 \%$ of total consumption, and in 2018, the last year for which there are available complete data, the share was $17.98 \%$, the main renewable energy sources used "in the energy consuming sectors being biomass for heating and cooling, hydropower and wind for electricity and biofuels for transport" (COM 952, 2020).

Based on this evolution, taking into account the main scenarios, it is found that "the EU is on track to achieve the 2020 renewables targets, but greater progress is still needed in some Member States" (COM (2020) 950, 2020). However, in order to assess the feasibility of achieving the 2020 target, a modeling exercise was carried out and based on the data obtained it is estimated that in 2020 the EU will reach a share of $22.8 \%-23.1 \%$ of renewable energy from the total energy consumed (COM (2020) 950, 2020).

From the above it can be seen that the measures taken at EU level so far have encouraged states to invest in renewable energy, but energy security, seen as an essential condition for ensuring national and collective security, is a very ambitious and difficult goal to be reached.
The comparative analysis of the main EU energy indicators for the period 2014-2018 can give us an idea of the degree of implementation of the EU energy security strategy and how to meet the main objectives set for Member States. In order to achieve energy security, which means providing the energy resources needed for the functioning of all branches of the European economy, maintaining the living standards of the population, creating a sense of security and confidence and reducing tensions that can affect the security of states, high efforts aimed at diversifying sources and resources, identifying new transport colors, increasing energy efficiency and reducing consumption, reducing dependence on imported resources, while promoting sustainable development, etc. are needed.

Although in 2014-2018 the share of energy from renewable sources increased in the European energy mix and it is very likely that official data for 2020 will confirm the achievement of the target at European level and at the level of each Member State, the analysis of the evolution of dependence on the main types of energy resources outside the EU, as well as the consumption of energy resources, may give us a less ideal picture of the possibility of ensuring energy security in the short and medium term. Thus, in the analyzed interval we can observe an increase of dependence on Russia in terms of coal and other solid fuels. We can also say that the security of supply of coal from external sources can be endangered by intentional acts or natural events or crises of any kind in different parts of the globe as the EU imports $95.4 \%$ of the amount of solid fuels consumed from only 7 states, some of them at appreciable distances from the European space (Table no. 1), which implies high transport costs and a relative dependence on weather conditions. 
Table no. 1

Evolution of EU coal imports by country of origin (as a percentage of total imports)

\begin{tabular}{|c|c|c|}
\hline \multirow{2}{*}{ Country of origin } & \multicolumn{2}{|c|}{ Year } \\
\cline { 2 - 3 } & 2014 & 2018 \\
\hline Russia & $27.7 \%$ & $42.4 \%$ \\
\hline USA & $18.7 \%$ & $18.6 \%$ \\
\hline Colombia & $18.8 \%$ & $13.4 \%$ \\
\hline Australia & $8.3 \%$ & $11.8 \%$ \\
\hline Indonesia & $4.7 \%$ & $3.8 \%$ \\
\hline South Africa & $10.0 \%$ & $2.8 \%$ \\
\hline Canada & $3.5 \%$ & $2.6 \%$ \\
\hline
\end{tabular}

The available data show that the situation of the EU's dependence on coal from outside the Union did not improve during the period under review, even worsened if we take into account that it has increased its dependence on Russia, a state that is one of the main suppliers of energy resources to the EU and which can take advantage of the situation at any time and use energy resources as a tool of pressure. This attitude can be favored in the short term, but in the long run it could prove harmful to Russia, as it depends to an even greater extent on the EU for the dissemination of energy resources. If the EU can find alternatives to energy from Russia, especially in the medium term, for Russia is not possible to replace the UE as the main beneficiary of energy resources.

However, in the analyzed period a decrease of consumption can be observed, from 142152 mtoe (million tons of oil equivalent) to 117663 mtoe, which means a difference of $17.32 \%$. This decrease can be attributed to EU policies to reduce pollution and promote cleaner energy, including to decarbonise the economy and increase energy efficiency. The use of coal is still a viable option for many countries because it is a cheap, relatively abundant, easy-to-use energy resource, does not require complex infrastructure for exploitation, transport, storage and use, but has the disadvantage of polluting a lot.

Another energy resource that EU countries import in very large quantities is oil, and $78.1 \%$ of the imported quantity comes from only 8 countries (Table no. 2). Among the oil-supplying states, Russia stands out again, supplying about $30 \%$ of the total quantity. Oil is transported either by using oil tanks or by using existing pipelines, which can ensure a relatively constant flow of oil, regardless of weather conditions. However, oil infrastructure needs additional protection as it can become targets of terrorist attacks or priority targets in the event of a conflict.

Table no. 2

Evolution of EU oil imports (as a percentage of total imports)

\begin{tabular}{|c|c|c|}
\hline \multirow{2}{*}{ Country of origin } & \multicolumn{2}{|c|}{ Year } \\
\cline { 2 - 3 } & 2014 & 2018 \\
\hline Russia & $31.7 \%$ & $29.8 \%$ \\
\hline Iraq & $4.8 \%$ & $8.7 \%$ \\
\hline Saudi Arabia & $9.0 \%$ & $7.4 \%$ \\
\hline Norway & $9.3 \%$ & $7.2 \%$ \\
\hline Kazakhstan & $6.7 \%$ & $7.2 \%$ \\
\hline Nigeria & $8.4 \%$ & $7.1 \%$ \\
\hline Libya & $3.4 \%$ & $6.1 \%$ \\
\hline Azerbaijan & $4.7 \%$ & $4.6 \%$ \\
\hline
\end{tabular}


Oil and refined petroleum products are a basic resource for the EU economy, but also for the population, as the transport sector is highly dependent on these resources. The short-term situation is unlikely to change radically, but in the medium term, in the horizon of the 2030s it is possible to see a considerable decrease in the consumption of petroleum products, as states will ban or limit the use of vehicles with internal combustion engines, encouraging electric vehicles. The evolution of technology will allow the expansion of transport using electricity not only at the population level but also in the transport industry, and the efficiency of electric motors will revolutionize even air transport, one of the largest consumers of petroleum products.
Regarding the consumption of oil and derived products, at the EU level there is a slight increase in the analyzed range, from 493039 mtoe to 517619 mtoe, which in percentage translates into an increase of $4.98 \%$.

Natural gas consumption at EU level registered a sustained increase in the analyzed period, from 231764 mtoe in 2014 to 303635 mtoe in 2018, which means an increase of $31 \%$. This increase can be attributed to growing interest placed on the use of natural gas in industry as it is less polluting than oil or coal and to the development of new gas pipelines between Russia and Europe, especially between Russia and Germany. EU imports $77.8 \%$ of total gas imported from just 5 countries, of which Russia ranks first with $40.4 \%$ of total (Table no. 3).

Table no. 3

Evolution of natural gas imports at EU level (as a percentage of total imports)

\begin{tabular}{|c|c|c|}
\hline \multirow{2}{*}{ Country of origin } & \multicolumn{2}{|c|}{ Year } \\
\cline { 2 - 3 } & 2014 & 2018 \\
\hline Russia & $41.2 \%$ & $40.4 \%$ \\
\hline Norway & $26.0 \%$ & $18.1 \%$ \\
\hline Algeria & $13.0 \%$ & $11.8 \%$ \\
\hline Qatar & $3.7 \%$ & $4.6 \%$ \\
\hline Nigeria & $1.6 \%$ & $3.0 \%$ \\
\hline
\end{tabular}

The above data show that the dependence of EU countries on a small number of energy resource providers can pose a threat to national and collective security, and that Russia provides over $30 \%$ of total EU imported resources, which places it in a dominant position. The development of new energy infrastructure projects linking European states to other oil-rich areas can gradually reduce dependence on Russia and help strengthen collective security.

\section{EU Energy Security Perspectives}

Europe's energy situation is not very gratifying, given that "the European continent is the least contributor of all the world regions in global energy production equation" (Elbassoussy, 2019). Based on this reality, the EU must show a proactive attitude in order to ensure its necessary resources and strengthen its energy security in the short, medium and long term. The energy security strategy was one of the EU's attempts to set common goals and focus member states' efforts in the same direction. The time elapsed since the elaboration of the strategy, in 2014 and until now shows that the measures established by the EU energy security strategy developed in 2014 have not been particularly effective, if we take into account that the degree of dependence of EU states on energy resources of imports increased from $53.49 \%$ in 2014 to $55.68 \%$ in 2018, in gross figures the amount 
imported increasing from 887569 mtoe to 952280 mtoe, which means an increase of $7.29 \%$. Also in this period there is an increase in the consumption of energy resources by $2.63 \%$, from 1511972 mtoe to 1551757 mtoe. Progress can be seen in increasing national storage capacity, which contributes to creating a reserve of capacity that can be used in the event of a supply disruption. There is also visible progress towards the interconnection of Member States, through investments in Projects of Common Interest in the field of energy, as a "well-interconnected energy infrastructure is a pre-condition for establishing an integrated, competitive and sustainable internal energy market in the European Union and is also a pre-requisite for a resilient Energy Union which provides EU consumers with secure, sustainable, competitive and affordable energy" (SWD $395,2019)$. These projects are funded by the EU and aim to develop a high-performance, secure energy infrastructure that will allow the unhindered flow of energy resources between EU countries. In the case of our country we can mention the project aimed at interconnecting Bulgaria, Romania, Hungary and Austria in terms of natural gas transmission (BRUA gas pipeline), which reduces the vulnerability to a deliberate or accidental interruption of supply. This gas pipeline was completed in Romania on November 22, 2020 (Rusu) and allows to increase the transport capacity from Romania to Hungary to 1.75 billion cubic meters of gas per year, and to Bulgaria up to 1.5 billion cubic meters of gas annually. This project is important for increasing the energy security of Romania, but also of the other states in Central and Eastern Europe, as it can ensure the transport of exploited gases from the Black Sea, but also the interconnection with other gas pipelines connecting the Caspian and Mediterranean region with Europe, which can significantly reduce dependence on Russia.
An asset for the EU in ensuring energy security is the progress made in promoting renewable energy, which will make a decisive contribution to achieving medium- and long-term goals. In order to encourage States to make efforts to expand their renewable energy production capacities, but also to boost research in the field, the European Commission supports all efforts aimed at (European Parliament, 2018): reducing the cost of capital for renewable energy projects; developing projects and programs aimed at integrating renewable sources into the energy system, increasing the flexibility of this system, maintaining the stability of networks and managing their congestion; the development of energy transport and distribution infrastructure, development of smart grids, storage facilities and interconnections, with the aim of achieving a $15 \%$ electricity interconnection target by 2030 , in order to increase the technical feasibility and economic accessibility of energy from renewable sources in the energy system; strengthening regional cooperation between Member States and between Member States and third countries, through joint projects, joint support schemes and the opening of support schemes for electricity from renewable sources to producers located in other Member States, etc.

\section{Conclusions}

The importance of energy resources for the proper functioning of the economy, for maintaining a high standard of living and for upholding the democratic values of EU states, for maintaining stability and security is undeniable, and from this perspective ensuring energy security becomes an imperative, because energy security strengthens national and collective security by removing the multiple vulnerabilities that arise from it and by strengthening all the power instruments of states and alliances. 
In order to ensure energy security in the medium and long term, action must be taken in an integrated manner, in several directions, with the involvement of national and supranational actors. The EU needs to develop partnerships in the field of energy, transform dependence into a constructive interdependence and take concrete steps to ensure long-term energy stability, which is not to be confused with energy independence. The measures proposed in the EU Energy Security Strategy, although not very effective in the short term, create the framework for the development of the Energy Union project, which is based on five complementary dimensions, designed to help strengthen sustainability, competitiveness and energy security (COM 80 final, 2015):

- energy security, solidarity and trust;

- a fully integrated European energy market;

- energy efficiency in support of demand moderation;

- decarbonization of the economy;

- research, innovation and competitiveness.

All this contributes to the realization of the EU's energy security as a whole, as it is not enough for each state to take steps to ensure its own energy security, but common opportunities must be exploited and the effort shared.

\section{"The European Union's energy} policy stresses the need for secure energy supplies, sustainable energy consumption, lower fossil fuel dependence and improvements in energy efficiency" (EUROSTAT, 2020), but the strategies developed and the policies implemented by the EU are only the first step towards ensuring long-term energy security (Bojor, Cîrdei \& Pricopi, 2018).

Energy security can be strengthened by working to increase energy efficiency, promote sustainability and sustainable development, create the conditions for diversifying the energy mix and multiplying energy sources and transport routes, securing critical energy infrastructure directly, but also by promoting security and regional stability, by promoting renewable energy, etc. By achieving energy security, EU states not only maintain a proper pace of development, but also strengthen national and collective security.

In the current context, when the global COVID 19 pandemic has forced governments to take drastic measures to limit the spread of the virus, there can be a decrease in the consumption of energy resources and an improvement in the energy situation of EU countries as a whole. Although only after the publication of official data will we have a correct picture of the changes that have taken place in the energy field, it is certain that the sectors that consume the most energy resources: transport and industry have reduced their activity, which has led to a decrease in consumption, as well as to the decline of imports of energy resources. This situation can contribute to the achievement of energy security in the short term, but also offers opportunities in the medium and long term, as states can take advantage of this situation and try to perpetuate the situation and encourage rational consumption and promote renewable energy.

The adoption of measures to ensure energy security in the medium and long term actually creates the conditions for strengthening national and collective security and for guiding relations between energy-owning and consumer-friendly states in order to promote cooperation and dialogue. States with energy resources should be encouraged to support further developments towards reducing consumption and diversifying the energy mix by involving them in major projects and providing real development alternatives. 


\section{REFERENCES}

Bojor, L., Cîrdei, A., \& Pricopi, M. (2018). Aspecte de actualitate privind politica de securitate și apărare a Uniunii Europene. Sibiu: Editura Academiei Forțelor Terestre "Nicolae Bălcescu".

COM 330 final. (2014). Communication from the Commission to the European Parliament and the Council. European Energy Security Strategy. Brussels.

COM 80 final. (2015). Pachet privind Uniunea Energetică - Comunicare a Comisiei către Parlamentul European, Consiliu, Comitetul Economic și Social European, Comitetul Regiunilor și Banca Europeană de Investiții. O strategie-cadru pentru o uniune energetică rezilientă cu o politică prospectivă în domeniul schimbărilor climatice. Brussels.

COM 950 final. (2020). Report from the Commission to the European Parliament, the Council, the European Economic and Social Committee and the Committee of the Regions. 2020 Report on the State of the Energy Union pursuant to Regulation (EU) 2018/1999 on Governance of the Energy Union and Climate Action. Brussels.

COM 952 final. (2020). Raport al Comisiei către Parlamentul European, Consiliu, Comitetul Economic și Social European şi Comitetul Regiunilor. Raport privind progresele inregistrate în domeniul energiei din surse regenerabile. Brussels.

Elbassoussy, A. (2019). European energy security dilemma: major challenges and confrontation strategies. Review of Economics and Political Science Vol. 4, no. 4, Emerald Publishing Limited, 331.

European Parliament, Council of the European Union. (2018). Directive (EU) 2018/2001 of the European Parliament and of the Council of the 11 December 2018 on the promotion of the use of energy from renewable sources (recast). Official Journal of the European Union, no. L328/82, 24-25.

EUROSTAT. (2020). Energy, transport and environment statistics - 2020 Edition. Luxembourg: Publications Office of the European Union.

Rusu, F. (2020). Transgaz a finalizat lucrările la gazoductul BRUA într-o zi liberă, de duminică. Cel mai important proiect de investiție al companiei, în valoare de aproape jumătate de miliard de euro - INFOGRAFIC, available at: https://www.profit.ro/povesti-cuprofit/energie/exclusiv-transgaz-finalizat-lucrarile-gazoductul-brua-intr-zi-libera-duminicacel-important-proiect-investitie-companiei-valoare-aproape-jumatate-miliard-euro-infografic19625638 , accessed on 23 November 2020.

SWD 395 final. (2019). Commission staff working document accompanying the document Commission Delegated Regulation amending Regulation (EU) No 347/2013 of the European Parliament and of the Council as regards the Union list of projects of common interest. Brussels. 